\title{
The Theoretical Basis for Specialized English and Application of Specialized English Teaching and Learning Practices: Research on a Vietnamese Higher Education Institution (UTC.HCMC)
}

\author{
Ha Thi Thanh* \\ University of Transport and Communications, Hanoi, Vietnam \\ *Corresponding Author \\ Ha Thi Thanh
}

Article History

Received: 25.08 .2020

Accepted: 02.09.2020

Published: 06.09.2020

\begin{abstract}
In order to respond well to urgent needs in the current globalization context, the Government of Vietnam has been paying special attention to the education and training sector of the country. Many education and training policies and policies have been introduced in order to comprehensively innovate and improve the quality of this highquality human resource training. Especially, improving the quality of English teaching and learning at training institutions, in which specialized English plays an important role. This study specifies the rationale for teaching and learning specialized English and specialized English teaching activities at Vietnamese training institutions, from there apply to teach at the University of Transport and Communications in Ho Chi Minh City (UTC.HCMC).
\end{abstract}

Keywords: Specialized English, higher education, Vietnam, UTC.HCMC.

\section{INTRODUCTION}

In the general development of the world, the trend of globalization and cooperation for mutual development is indispensable. Accordingly, English is considered an international language, a means for international communication commonly used in the world. Like a useful means, a bridge connecting each individual to the world, English makes anyone feel more confident in a challenging life in the context of a growing market economy like the current.

Vietnam is a developing country and English is an effective support tool for integration and cooperation to access the world's advanced working environment and technology. Since 2015, the ASEAN community has been implemented, this is an opportunity and a challenge for Vietnam. After 2015, national barriers were removed, instead of the multicultural international integration environment of the countries in the community, leading to freedom of movement and job-seeking opportunities in real estate. Any country in the community becomes easy and convenient.

The country of Vietnam is transforming, actively integrating into the world economy in all aspects, and teaching and learning English in the current education program in our country, is very interested in the state and society and focus. Many seminars and reforms have been organized and implemented at all levels on such issues as curriculum content, teaching methods innovation, training and improving quality of teachers, equipment, teaching materials, reforming test methods, evaluating and recognizing learners' qualifications in line with international standards. However, these efforts have not met the requirements of an increasingly dynamic and changing society today. Therefore, many issues need to be considered in a more specific and detailed way, including teaching and learning English at the university level in general and especially the teaching of specialized English at universities study in particular.

The results of a field survey by the National Academy of the United States in 2006 commented on Vietnam's teaching and higher education methods as follows: "Teaching methods are ineffective, too dependent on lectures. process and use less active learning skills, resulting in less interaction between students (students) and faculty inside and outside

Copyright @ 2020: This is an open-access article distributed under the terms of the Creative Commons Attribution license which permits unrestricted use, distribution, and reproduction in any medium for non commercial use (NonCommercial, or CC-BY-NC) provided the original author and source are credited. 
the classroom; too much emphasis on memorization of knowledge without emphasis on conceptual learning or advanced learning (like analysis and synthesis), resulting in superficial rather than intensive learning; Students learn passively" [1].

Moreover, teaching and learning specialized English, in particular, has not escaped the influence of examoriented education. Most students value exam results more than the ability to use English as a dynamic communication language. According to Hoang Van Van, the purpose of learning a language is to be able to use it to meet your own communication needs with another person in that language [2]. However, most students do not understand this important purpose.

Therefore, many students take the English writing exam with high scores but their communication skills are not satisfactory, leading to the failure to meet the expectations and needs of the employers when they graduate from university. Before that situation, research the theoretical basis from which to apply in teaching and learning specialized English at UTC. HCMC is a pressing issue nowadays.

\section{LiTERATURE REVIEW}

In order to well meet the urgent needs in the current context, the Party and the State of Vietnam have been paying special attention to the education and training sector of the country. Many education and training policies and policies have been introduced in order to comprehensively innovate and improve the quality of this high-quality human resource training. Especially to improve the quality of English teaching and learning at training institutions, specifically:

1. The project "Teaching and learning foreign languages in the national education system, stage 2008-2020" was developed by the Ministry of Education and Training and approved according to Decision No. 1400/QD-TTg dated September 30, 2008, of the Prime Minister (called Scheme 2020). Which gives the standard of English proficiency of learners applied according to the standards of the Common European Framework of Reference (CEF), specifically until 2030 [3]:

a. Students at colleges and universities not specializing in foreign languages have level B1 according to the European Framework of Reference;

b. Students at colleges and universities specializing in foreign languages have level B2 according to the European Framework of Reference.

2. To concretize Decision No. 1400, the Ministry of Education and Training has issued a 6-level language capacity framework for Vietnam use, issued together with Circular 01/2014/TT-BGDĐT dated January 24/2014 of the Minister of Education and Training, to unify the capacity requirements for all foreign languages in teaching, help learners understand the content and requirements for each competency level foreign language and self-assessment (output standards) to reach foreign language proficiency according to the 6-level according to the foreign language proficiency framework for specific Vietnam [3]:

a. Achieve competency level 3 (level B1 according to the European Framework of Reference) for colleges, universities not specialized in language;

b. Achieve competency level 4 (level B2) for colleges specialized in language;

c. Achieve competency level 5 (level $\mathrm{C} 1$ ) for universities specialized in language.

4. Especially for the 2016-2017 school year, the Ministry of Education and Training has issued Official Letter No. 5008/BGDĐT-GDĐH on guiding the implementation of the 2016-2017 school year tasks for higher education and college-level pedagogical training, specifically the 2016-2017 school year, the higher education sector and the professorship colleges Pham focused on performing the following general tasks [4]:

d. Continue to implement the Government's Action Program to implement the Resolution No. 29-NQ/TW dated November 4, 2013, of the Xth Central Executive Committee on fundamental and comprehensive innovation of education and training;

e. Implement the Education Sector's Action Plan to deploy the Government's Action Program to implement the Resolution of the 12th Party Congress and the National Assembly's Resolution on the 2016 - 2020 socioeconomic development plan;

f. Well implementing 9 key tasks and 5 major solutions of the entire Education and Training sector, especially the tasks and solutions to promote university autonomy and accountability, strengthen accreditation quality to replan the network of schools and improve the quality of training human resources, especially high-quality human resources and associated with the needs of the labor market. 
5. To achieve the educational goals set out, of which the important task is to improve the quality of foreign language teaching, especially English, universities and colleges need to perform the following tasks [4]:

a. Schools actively review the output standards of foreign languages, especially English and the output standards of high-quality training disciplines to adjust to equal or higher than the target of Project 2020; actively implementing specialized curriculum in English and enhanced English teaching program for students in a rich form, suitable to the conditions of the school;

b. Complete programs, documents, textbooks, foreign language materials system (printed and electronic documents) for basic language programs, intensive language programs, specialized foreign languages, training programs specialized language and bilingual training for some subjects/disciplines, especially English to meet the training program objectives and requirements of the training industry, of the region or locality, in accordance with the needs of learners;

c. There is a plan to foster and standardize the contingent of foreign language teachers, lecturers specialized in foreign languages to meet the standards of foreign language competencies, and take measures to maintain their competencies after having qualified training;

d. Raising awareness and responsibility of administrators, lecturers, and students in the school on the work of popularizing English; launching the movement, forming a favorable environment to support learning and selfstudy to improve English proficiency for students and lecturers; motivating staff, faculty, and students to learn English;

e. Increasing investment in facilities for teaching and learning, testing and evaluating foreign language ability; increase the application of international standards on foreign languages in the assessment of inputs and outputs of training levels and staff and lecturers in schools.

\section{Theoretical Basis for Specialized English}

History of specialized English development:

Hutchinson and Waters is named the father of specialized English, were giving 3 reasons why specialized English develops:

+ After World War II, English became the international language, the language of science and technology, the language of commerce, the language of sports, etc. With the goal of learning English to serving the work, so specialized English was born;

+ A revolution in language teaching methods was born: language teaching no longer only teaches to know the language but teaches so that learners can use language in communication. This is the second reason that specialized English is born because learners can learn English and use English directly for their work;

+ The revolution in education to serve the needs of students is born. Education has moved to a new stage: teaching to serve the needs of learners and this is the third reason for specialized English to be born. At this stage, learners do not want to learn English in general but they want to learn English they need and that is specialized English.

\section{$\mathrm{Oz}$ is a linguistic researcher who describes the development of specialized English into 3 phases:}

+ Stage 1: specialized English began to develop after World War II when the number of people learning English for scientific research and learning English to work in English-speaking countries increased significantly.

+ Stage 2: specialized English continues to develop in the late 20th century when educators realize that teaching English is to teach learners what they need. What English learners to do: to go to work in the tourism industry or to work in the trade industry or to research science, technology, etc.

+ Stage 3: From the 1990s onwards, due to the development of science, technology, and culture such as journalism, the higher the need to learn specialized English raises a problem:

To add a specialized English teaching team, comprising a force mainly of foreign language teachers and should add specialized teachers who meet the foreign language teaching criteria. From this stage, the language educators give out the following requirements: English courses must be tailored to the needs of learners; for example, designing a tourism English course for students in tourism; or designing an English banking and finance course for students of banking and finance, etc., with the above point of view, there are currently 49 majors of specialized English documents on the market. 
World researchers all affirm that specialized English was born after the 2nd world war and developed into a discipline in the field of English language: specialized English; It was further developed when linguists established the specialized English world magazine.

Definitions and concepts of specialized English: The linguists have different definitions of specialized English, but they all have in common about specialized English as follows:

+ According to Wright linguist [5], specialized English in English is written as ESP: English for specific purposes. Temporarily translated "English used for different teaching-learning purposes, or linguistic circles or called specialized English

+ According to researchers Duley Evans \& Hutchinson [6]: "ESP language is specialized in language teaching, so all content, teaching methods are derived from the reason of language teaching". They pointed out that "there is no difference between basic English and specialized English, just the content of the instruction. The teaching process should be to teach Basic English first and then to teach specialized English. Teaching English specialized is language teaching based on the needs of learners, will save time and money for learners, beneficial for learners in professional development".

Learner: Dudley Evans and John states that learners participating in specialized English courses are students at universities or colleges, or are already working. Students taking a specialized English course should have an intermediate level of Basic English or at least beginner level [7].

It is surprising that there is a coincidence with studies from countries such as Iran, Taiwan, China, and Korea: students who study specialized English are better than Basic English because students have specialized English motivated to study higher and easier when having some specialized knowledge.

Thus, a successful specialized English learner must be someone who knows how to bring knowledge and skills to be applied in their work; can read books, newspapers about their major, can translate documents to supplement their work, can write reports, correspondence, or answer the phone, talk to others, etc., an environment where English is used for work, or there are foreign elements in some fields of work. The research by Zhang and Bouzidi has shown that learning specialized English must be derived from the practical needs of learners, from the need to use language to perform public functions work at work.

Teacher: Who will participate in specialized English teaching: Eliss and Jonson and Duley suggested [7]:

+ Specialized English teachers must be graduate students in the English language because specialized English teaching is language teaching, not professional teaching. Specialized English teachers must know how to stimulate students' interest in learning English so that they can use English to serve their specialties. Teachers of specialized English not only convey knowledge but must be the ones who attract students to use that knowledge to communicate. Specialized English teachers must be more flexible listeners to students in order to join them effectively in lectures.

+ Specialized English teachers must have basic knowledge of that major and they must be the teacher can design courses and develop materials.

+ A specialist English teacher must be a researcher to develop materials and give appropriate language teaching methods.

+ Teacher of specialized English must be someone who can cooperate with colleagues and students and must have a positive attitude to guide students to love the job.

Course design and material development: According to Hutchinson and Waters, the design of a specialized English course must be based on the following principles [1]:

+ Course design must be based on language teaching point of view,

+ Course design must focus on developing language skills,

+ Course design must suit the needs of learners.

+ Course design must focus on developing material resources; Materials of specialized English courses include specialized materials, videos, chart diagrams, all documents and data related to the discipline. Teaching materials must have content relevant to that major. Designing documents must clearly show the viewpoint of teaching English for learners to use in communication, not just knowledge of English. Documents must design large exercises that are suitable for communication needs. Specialized English courses can use commercially 
available materials or write their own material, however researchers have shown that there is no document that is $100 \%$ suitable for teachers to always adjust while teaching.

Teaching methods: Teaching and learning specialized English is language teaching and learning, so the teaching method follows the method of teaching a foreign language based on a learner-centered basis.

\section{Applying Specialized English Teaching and Learning Practices at UTC. HCMC}

In fact, the teaching of specialized English is not out of the goal of fully developing 4 language skills (listening, speaking, reading, and writing) for students like the Basic English foundation (General English). However, specialized English is intended for professional purposes, for specific purposes, to focus a learner's attention on language and communication requirements in a particular area of expertise [2]. Since the 50s of the 20th century, the teaching of specialized English in advanced countries has gone through many periods of development with a number of typical books and different approaches from basic to specialize in many fields. For example, textbooks such as "English Engineer" for students in construction engineering, "English for Economics" for students in Economics, or "English for Accounting" for students in Accounting, "Mechanical English" for mechanical engineers, etc.

It can be said that the main problem of specialized English teaching is to build student's skills to communicate and use English specialized text in the field in which they are trained. In terms of programs and training objectives, teaching specialized English knowledge together with the development of communication skills is necessary. Because, according to the training program, students have been able to learn some Basic English modules and gain background knowledge in the specialized field through the modules in their mother tongue. But through the annual exam of the end of the specialized English module and through direct interviews in English with students who finished the specialized English module, the writer as a lecturer of specialized English for many years, they found that the basic communication skills and simple sentences of most of these students were very weak. Many classes even have more than $50 \%$ of students in a class who do not pass the course. Many students use English language structures and terminology such as Vietnamese structure and the pronunciation of words, especially students' specialized words incorrectly. This stems from many objective and subjective reasons and has been given the following by the writer as some typical shortcomings:

The time for Basic English modules in the first year at university is not much, not enough to foster language knowledge for students who are ready to study specialized English due to a large number of students entering university. Learning English is too poor. Universities often apply the general rules and set up training programs for basic English modules is only 8 credits. If students do not actively self-study after-hours in class, they will not be able to meet the language skills requirements to continue studying in specialized English. In fact, many students, when studying specialized English, still owe the Basic English modules. This hinders the acquisition of knowledge as well as the language skills of students in specialized English teaching.

The fact is that students in a classroom come from many localities inside and outside the province - most of them come from districts, communes and rural areas with different learning conditions, so there is inevitably a diversity of qualifications and English competence. That is not to mention their different learning motivations. Many students are not aware of the importance of the English language as the key to applying for jobs and succeeding in the future. This means that with the same content and teaching methods, but the level of learning and practice of each student in a specialized class has a big difference. Therefore, some difficulties arising in teaching and learning process are inevitable.

On the other hand, the number of specialized English classes is often over 50 students. Therefore, teachers' attention to language development during lessons for each student is very limited. Teachers have to spend a lot of time stabilizing order, and managing and covering all students, especially students sitting at the end of the class, is a big difficulty for teachers. Therefore, many students do not have the opportunity to practice and develop language skills, especially for passive students who are shy about their own language knowledge. This number of students is usually not small due to the starting point of students' circumstances and qualifications as mentioned above.

The time for specialized English courses is not much, mostly 2 credits (30 periods), there are only a few majors with 2 to 3 credits such as economics or tourism. Providing new knowledge in parallel with the practice of skills will be omnipresent, especially for students who do not actively explore and research materials before and after school, although teachers have always tried their best make the maximum use of instructions for students to self-study, practice, and practice outside of class hours.

Facilities for specialized English classes are limited, there are no specialized rooms, and the projector system is not fully equipped, which is really necessary for illustrating activities or arts specialized language in teaching hours. Students will be more receptive to concepts, knowledge and remember more quickly, and be passionate about lectures through vivid and realistic images. 


\section{CONCLUSION}

The fact about the English communication level of university graduates is alarming bells about programs and training methods in universities. Mr. Michael - Technical Director of Intel Vietnam said: "Learning results must apply theoretical concepts to practical applications, etc. A "comprehensive" student with high scores is not enough. , must have communication skills, etc.," and he suggested that in improving the quality of higher education, it is necessary to" revolutionize the curriculum, in which attention should be paid to English because the English communication of students is too weak ".

The above recommendations certainly entail additional costs for training and human resources. But I think, with the policy of innovative autonomy in educational management in government universities, along with the determination to find effectiveness in teaching and learning specialized English, we must have some changes, including changes in perception. Proposing an idea is really just the beginning. But our full awareness and that of students about the entire process of teaching and learning English in general and specialized English, in particular, are in line with socio-economic conditions and towards the new higher education reform is an important issue. At UTC. HCMC for many years, despite a change in methodology, has not yet achieved the desired results. That problem requires the school's leaders to invest more in all aspects to create a favorable environment for teaching and learning English in general and specialized English in particular.

\section{REFERENCES}

1. Hutchinson, T., \& Waters, Alan. (1987). English for specific purposes: A learner-centered approach. Publishing house Cambridge University.

2. Van, H. V. (2008). The current situation and issues of the teaching of English in Viet Nam and Japanese. Journal of Language, 4(6).

3. Ministry of Education and Training. (2008). Teaching and learning foreign languages in the national education system, stage 2008-2020.

4. Ministry of Education and Training. (2016). Guiding the implementation of the 2016-2017 school year tasks for higher education and college-level pedagogical training.

5. Annie, W. (1993). English for specific purposes. Cambridge University Press.

6. Dudley, E., \& John, M. J. (1998). Developments in English for specific purpose. Cambridge University Press.

7. Ellis, M., \& C. Johnson. (1994). Teaching business English. Hong Kong: Oxford University Press. 